\title{
Qualification and Validation of USP Apparatus 4
}

\author{
Jon S. Kauffman, Ph.D., Director \\ Pharmaceutical Method Development and Validation \\ Lancaster Laboratories, 2425 New Holland Pike, Lancaster, PA 17605
}

email:jskauffman@lancasterlabs.com

\section{Summary}

$\mathrm{D}$ issolution applications involving USP Apparatus 4 have increased recently (see article by Will Brown, USP). Many novel dosage forms are not amenable to the conventional dissolution techniques such as USP Apparatus 1 (rotating basket) or USP Apparatus 2 (rotating paddle). The flow through cell design of the USP Apparatus 4 is a more practical approach to dealing with microspheres, liposomes, stents, and other novel dosage forms. Lancaster Laboratories uses the Sotax Apparatus 4CE 7 SMART System. This system includes a 7-piston pump, a media switching unit, a heating bath, flow through cells, a fraction collector, a data system, and an Agilent 8453 UV/Vis spectrophotometer. This system can be operated in an open system configuration (Figure 1) where media flows through the cell containing the drug product to a fraction collector or in a closed system configuration (Figure 2) where a finite amount of media is constantly recirculated through the cell. This article will discuss the qualification and validation activities of this equipment to support current good manufacturing practices (cGMPs).

\section{Pre-Validation Activities}

Ideally, the process should be started before the equipment is ordered, with several pre-validation activities. Initially, a vendor evaluation is performed. In some cases this may require an on-site audit of the vendor but typically this can be done without a visit. Examples of the information gathered include general information about the vendor and the product to be purchased, the vendor's quality and development practices and their overall understanding of validation, cGMPs, and 21 CFR Part 11. Important also is determining the extent of the vendor's ongoing service after purchase. If vendor testing protocols are available, they should be requested for review. At this time, internal role assignments are made for System Owner, System Administrator, Metrology Contact, Validation Contact, Computer Support, and Quality Assurance. Each of these roles has a specific responsibility throughout the process. This information is pulled together in the Validation Project Plan (VPP), a document that describes the scope of validation, vendor, installation location, software/firmware version, description of the system, roles and responsibilities, functional requirements, testing to be performed, and support and maintenance required.

\section{Functional Requirements}

Defining the functional requirements is key to the validation of any new system or equipment and should answer the following questions.

What is the intended use/purpose of system?

What functions must the system perform?

What are the environmental requirements?

What are the performance requirements?

What are the security and Part 11 requirements?

What are the data output and format requirements?

Below are some specific examples of functional requirements for the Sotax Apparatus 4 system:

- Pump must be capable of adjustable flow (typical flow rates are 4,8, or $16 \mathrm{ml} /$ minute)

- The tubing, which supplies dissolution medium from the pump to the cells, is to be made of polyteflon with a 1.6-mm inner diameter.

- Cells must fit into the holder so that they may be immersed in water bath that is maintained at $37+/-0.5^{\circ} \mathrm{C}$.

\section{Qualification Testing}

The functional requirements are then assessed through qualification testing. The various tests include Installation
Closed System Configuration with UV/VIS

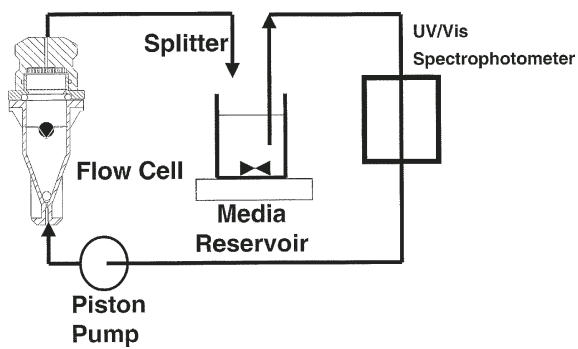

Figure 1.

Open System Configuration

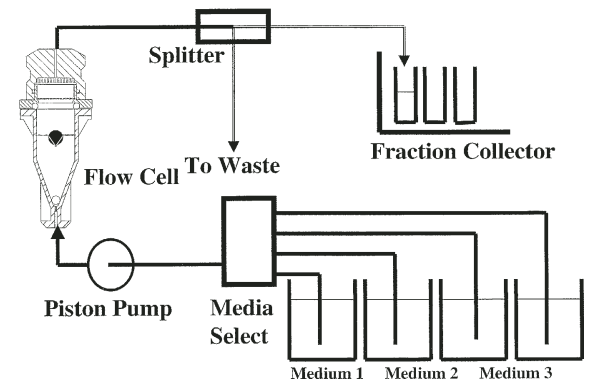

Figure 2. 
Qualification (IQ), Operational Qualification (OQ), Performance Qualification (PQ), and Part 11 Compliance Testing. The IQ confirms that the system is installed correctly and meets the vendor or manufacturer's specifications. Equipment identification (serial numbers, etc.) and utility requirements (gas, water, etc) are evaluated at this time. The OQ establishes that the equipment can operate within specified tolerances and limits. The PQ testing qualifies the system to its specific performance and is typically done by the user. For this Apparatus 4 system, Sotax performed IQ/OQ on the Apparatus 4 and associated software; Agilent performed IQ/OQ on the UV/VIS spectrophotometer and Chemstation; and Lancaster Laboratories performed PQ and 21 CFR Part 11 testing.

Major checkpoints addressed in the IQ/OQ of the Sotax Apparatus 4 system include the CE 7 SMART, media pipes, piston pump, C613/615 fraction collector, MS 47 media selector/splitter valve bar, and blowout connection. USP

\section{Table 1. Performance Qualification Tests}

\begin{tabular}{|c|c|}
\hline Test & Specifications \\
\hline $\begin{array}{l}\text { Fill a cell with the } 100 \% \text { Sali- } \\
\text { cylic acid standard and } \\
\text { measure with Chemstation. } \\
\text { Refill the cell and read } 4 \text { more } \\
\text { times for a total of } 5 \text { readings. } \\
\text { Calculate the RSD of the } 5 \\
\text { readings. }\end{array}$ & $\begin{array}{l}\text { RSD of the } 5 \text { readings should } \\
\text { be } \leq 3.0 \%\end{array}$ \\
\hline $\begin{array}{l}\text { Read each of the } 5 \text { linearity } \\
\text { standards of Salicylic acid in } \\
\text { duplicate, refilling the cell for } \\
\text { each reading. Log out of } \\
\text { ChemStation Software. }\end{array}$ & $\begin{array}{l}\text { Correlation coefficient of the } \\
\text { duplicate readings of the } 5 \\
\text { standards should be } \geq 0.99\end{array}$ \\
\hline $\begin{array}{l}\text { Fill the } 7 \text { reservoirs with } 50.0 \\
\mathrm{~mL} \text { of Milli-Q water. Manually } \\
\text { close the flow cell block } \\
\text { without the cells in place using } \\
\text { the Sotax screen. Start the } \\
\text { pump (set at } 25 \mathrm{~mL} / \mathrm{min} \text { ) on } \\
\text { the Sotax screen. }\end{array}$ & $\begin{array}{l}\text { The cell block will close and all } \\
7 \text { of the pistons will start to } \\
\text { move. The tubes will fill and } \\
\text { the loop will be filled with } \\
\text { Milli-Q water, returning to their } \\
\text { respective reservoirs to } \\
\text { recycle. The temperature will } \\
\text { reach } 37^{\circ} \mathrm{C} \text { and the Sotax } \\
\text { Screen will display"ready". }\end{array}$ \\
\hline $\begin{array}{l}\text { Stop the pump when all of the } \\
\text { lines are primed and there are } \\
\text { no bubbles remaining in the } \\
\text { lines. Individually for each of } \\
\text { the } 7 \text { lines, remove the'outlet' } \\
\text { line and place in the graduated } \\
\text { cylinder. Simultaneously start } \\
\text { the pump and the stopwatch, } \\
\text { collecting the eluate for } 60 \\
\text { seconds. Stop the pump imme- } \\
\text { diately when the timer ends. }\end{array}$ & $\begin{array}{l}25.0 \pm 2.0 \mathrm{~mL} \text { will be collected } \\
\text { in } 60 \text { seconds. Each line must } \\
\text { meet the criteria. } \\
\text { (return the collected eluate to } \\
\text { the correct reservoir so that } \\
\text { each loop still contains } 50 \mathrm{~mL} \text { ) }\end{array}$ \\
\hline
\end{tabular}

currently requires that only flow rate and cell temperature be validated. Temperature in the cells can be measured and validated with an additional temperature head.

\section{Table 2. Part 11 Compliance Testing Parameters}

\begin{tabular}{|c|c|}
\hline Test & Specifications \\
\hline $\begin{array}{l}\text { Admin:Power on the system. } \\
\text { Attempt to log onto the } \\
\text { system using an incorrect } \\
\text { password. Observe and docu- } \\
\text { ment the result. Replace the } \\
\text { incorrect password with the } \\
\text { correct one. Verify that the } \\
\text { user configuration window } \\
\text { can be accessed. }\end{array}$ & $\begin{array}{l}\text { Access to the system must } \\
\text { have been denied without the } \\
\text { correct network password, but } \\
\text { granted with the correct pass- } \\
\text { word. Admin role will have } \\
\text { access to the user configura- } \\
\text { tion window. }\end{array}$ \\
\hline $\begin{array}{l}\text { Verify that data backup is } \\
\text { being performed. Attempt to } \\
\text { restore backed-up files to orig- } \\
\text { inal location (paradox data- } \\
\text { base). }\end{array}$ & $\begin{array}{l}\text { Data backup is being } \\
\text { performed per SOP. Restored } \\
\text { data files have been success- } \\
\text { fully restored to the original } \\
\text { location. Contact the Network } \\
\text { Administrator to determine } \\
\text { the results. }\end{array}$ \\
\hline $\begin{array}{l}\text { Execute a sample run. Print a } \\
\text { hard copy of the raw data } \\
\text { generated. }\end{array}$ & $\begin{array}{l}\text { User role will allow for the } \\
\text { creation, naming, and saving of } \\
\text { the data generated. The User } \\
\text { role will also allow printing of } \\
\text { copies of the raw data. Hard } \\
\text { copies of data will be labeled } \\
\text { with data filename, date/time } \\
\text { of acquisition and analyst's ID. }\end{array}$ \\
\hline $\begin{array}{l}\text { Review hard copies for file } \\
\text { name, date and time of acqui- } \\
\text { sition, instrument ID, analyst } \\
\text { ID. }\end{array}$ & $\begin{array}{l}\text { Data printouts must show file } \\
\text { name, date and time of acqui- } \\
\text { sition, instrument ID, and } \\
\text { analyst ID. }\end{array}$ \\
\hline $\begin{array}{l}\text { Admin: Open the audit trail. } \\
\text { Print a copy of the audit trail. } \\
\text { Review file entries for user } \\
\text { name, date and time of } \\
\text { change. }\end{array}$ & $\begin{array}{l}\text { The audit is printable. Name, } \\
\text { date and time of change } \\
\text { should be present. }\end{array}$ \\
\hline $\begin{array}{l}\text { Attempt to change the system } \\
\text { clock by two hours. Attempt } \\
\text { changing the system date. }\end{array}$ & $\begin{array}{l}\text { The system must not permit } \\
\text { the User to affect changes to } \\
\text { the system's time and date } \\
\text { stamp. }\end{array}$ \\
\hline
\end{tabular}

Table 3. Calibrator Data

\begin{tabular}{|lccccccccc|}
\hline & \multicolumn{6}{c|}{ Percentage Salicylic Acid Released } \\
\cline { 2 - 9 } & C1 & C2 & C3 & C4 & C5 & C6 & Ave & \%RSD \\
\hline Analyst 1;Day 1 & 9.3 & 9.4 & 9.6 & 9.4 & 9.9 & 9.6 & 9.5 & 2.2 \\
\hline Analyst 2;Day 2 & 8.3 & 8.4 & 8.3 & 8.0 & 8.4 & 8.3 & 8.3 & 1.6 \\
\hline
\end{tabular}


Some specific example IQ/OQ tests are shown below.

- All channels for the piston pump CY7-50 are accessible (IQ).

- The pump can be calibrated to an accuracy of better than $+/-2 \%$ by measuring the mass of demineralized, degassed water delivered in 60 seconds (OQ).

The PQ tests to demonstrate that Sotax Apparatus 4 CE 7 $S M A R T$ meets all functional requirements not tested during IQ/OQ testing. These tests are also used to keep the instrument in a qualified state.

Some specific example PQ tests are shown in Table 1.

The Part 11 Compliance Testing focuses on security, data Integrity, data archival, and audit trail. Some examples of Part 11 compliance testing parameters shown in Table 2.

\section{Validation Summary Report}

After all testing is completed and reviewed; the validation summary report is prepared. This all-encompassing document covers the scope of validation and includes documentation, a summary of test results and any deviations, follow-up items and responsibilities. Most important, it includes the validation statement. This statement typically reads that the system can be put into production and describes any restrictions.

\section{Calibrators}

Once the system is validated it must be kept in a validated state. This is typically accomplished through change control and calibration or system suitability, done at specified intervals. At this time, the USP does not reference calibrator tablets for Apparatus 4. Salicylic Acid calibrator tablets are currently used for Apparatus 1 and Apparatus 2. The availability of a suitable calibrator is important since regulatory authorities, as well as the pharmaceutical industry, are very interested in ensuring that results of USP Apparatus 4 tests are comparable from day to day and laboratory to laboratory (1). The Fédéderation International Pharmaceutique (FIP) Working Group on Dissolution Testing has performed some work using salicylic acid tablets for Apparatus 4 and organized some collaborative studies.

Lancaster Laboratories has also carried out some testing using the experimental conditions shown below to determine if salicylic acid calibrator tables could be used for Apparatus 4.

Test material:USP Salicylic Acid calibrators, Lot O Flow-through cell: Piston pump ( $120 \pm 10$ pulses/min)

Cell: $12-\mathrm{mm}$ X 6 Cells (C1-C6)

Medium:Deaerated phosphate buffer solution

$\mathrm{pH} 7.4$

Temperature: $37^{\circ} \mathrm{C}$

*Sampling: 30 minutes

*Flow: $16 \mathrm{ml} / \mathrm{min}$

Analysis:UV $296 \mathrm{~nm}$
*The FIP Working Group recommended a flow rate of 16 $\mathrm{ml} / \mathrm{min}$, which exhibits the best reproducibility, and a testing time at 30 minutes. The six laboratories involved in the collaborative study observed $8-10 \%$ release under these conditions.

Lancaster Laboratories data agrees with that of the collaborative study (see Table 3). One difference between the two sets of data from Lancaster is that $0.5-\mathrm{cm}$ cells were used for the UV reading for day 1 data and $1.0 \mathrm{~cm}$ cells were used for day 2. Nevertheless, this preliminary data indicates that the Salicylic Acid calibrator tablets may be applicable to the Apparatus 4. Further studies are being performed by USP.

\section{Conclusion}

Apparatus 4 is a viable option for dissolution experiments with novel dosage forms. As with any instrument, validation is critical when working in a cGMP environment. Identification of a calibrator tablet will increase the confidence in data generated using this equipment.

\section{References}

1. T Foster, Brown W, USP Dissolution Calibrators: Reexamination and Appraisal, Dissolution Technologies, Volume 12 Issue 1, 6-8; 2005 